\title{
The Effect of Using Smart Board on Improving Ninth Grade Female Students' English Writing Skills In Southern Al-Mazar Directorate Education
}

\author{
Rafah Awad Abd-Alsalam Al-Tarawneh \\ Mu'tah University, Jordan \\ rafah@tti-jo.org
}

DOI: https://doi.org/10.36892/ijlls.v3i1.549

\begin{tabular}{|c|c|}
\hline $\begin{array}{l}\text { Received: } \\
\text { 10/03/2021 }\end{array}$ & $\begin{array}{l}\text { Abstract } \\
\text { To investigate the effect of using smart boards in improving English }\end{array}$ \\
\hline $\begin{array}{l}\text { Accepted: } \\
\text { 29/03/2021 }\end{array}$ & $\begin{array}{l}\text { writing skills for girls in the Southern Mazerate School District during } \\
\text { the first semester of 2017-2018. The researcher employed a pre-test and } \\
\text { a post-test to evaluate the students' writing skills. A group of } 67 \text { female }\end{array}$ \\
\hline $\begin{array}{l}\text { Keywords: } \\
\text { Smart Boardmodel, } \\
\text { English Writing } \\
\text { Skills }\end{array}$ & $\begin{array}{l}\text { grouents were randomly chosen to participate in the analysis. Ine first } \\
\text { the Mu'tahs school who used the Smart Boards as teaching aids. } 36 \\
\text { respondents were also trained by using the standard methodology from } \\
\text { Al-Mazar. This suggested that the two age ranges were comparable in } \\
\text { terms of their prior schooling, as well as their language capacity. The } \\
\text { validity and reliability of the study were established before and after } \\
\text { According to the results, there were major gaps between traditional } \\
\text { learning and Smartboard learning methods were used on Smartboard. } \\
\text { Several conclusions resulted from the findings. The Smartboard } \\
\text { approach should be applied in the educational phase in Jordanian } \\
\text { classrooms. Additionally, we could educate teachers on how to utilize } \\
\text { Smart Boards and motivate them to apply them in the instructional } \\
\text { process. }\end{array}$ \\
\hline
\end{tabular}

\section{INTRODUCTION}

Since the year 199s, English has been made a requirement in all Jordanian colleges. Yassin(2015) addressed the difficulty of teaching English in general, and even more so, writing. Specifically, he spoke about how modern international schools use the same teaching practices. Such a learning approach produces no worthwhile results when instructors neglect to account for students' differing learning preferences and cultural contexts. Teaching English in such a setting may be challenging or difficult for both ESL students and native speakers. Furthermore, a language is considered one of the most important elements of education. Its efficiency comes with mastery in production and reception. Even today in the eastern world, language production skills are given the significance of which writing is the most preferred outcome expected from students. This justification stands for the school where the students are required to master good writing skills.

In our day and age, technology plays a critical function in many facets of human life. The advancement of traditional teaching methods and human society through the use of computers Furthermore, information technology has impacted almost any area of human existence. it 
affects users' perceptions of implementing technical solutions each time they use it What's crucial to understand is that this movement, and how to use it, and who the main winners will be. Al-Koudairy was arrested this morning, charged with aiding and abetting a terrorist organization, and condemned to 20 years in absentia (2015)

Teachers such as Costley and Kevin(2014) describe an orientation that stresses student success when integrating technology as a teaching aid. Maximizing results and making decisions and carrying out educational strategies are being pursued by decision-makers and instructor staff members.With the vast society that we reside in, applying technology to teaching and learning is critical to impacting the students. Now, with the implementation of the Common Core Standards, the importance of using technology in schools would only increase.

Smartboards provide more advantages than machines, according to Al-Majali et al. (2016). Computers are configured for human use, while smart boards are not.

everybody should be aware of the value of technologies such as the SmartBoard Although video games, mobile phones, and iPods are prevalent in today's students' everyday lives, employing these emerging devices offer a new way of learning English terms. Evidence indicates that strong connections between learning technology and the students in the classroom boost both their academic performance and motivation levels. Students of the present day are more digitally linked than previous generations. proposes to improve the writing abilities of ninth-grade female students in the Al-Mazarate administration.

\section{Statement of the Problem:}

Vocabulary instruction in elementary schools is a difficult job, particularly with regard to students who possess a highly developed writing style. Learning English is difficult for those who are second or international language learners. In English as a second language, a researcher has found that some of her/his students experience difficulties. there were mistakes in their corrections, spelling, and their prose was not rational Most students' writing abilities appear to be sloppy. The issues concerning student writing abilities are listed in Tarawneh (2017). One of the latest training approaches used in this analysis is VAK (Visual Auditory Kinesthetic). The evaluation showed the educational challenges for the research to be localized in two distinct areas: one in the U.K. and one in the U.S. One of the studies showed that when students employ VAK strategy, there is a positive influence on their writing. In this case, a study like this would illustrate how critical it is to have a fresh perspective on teaching methods and therefore how vital it is to cultivate the abilities of teachers. This study concentrates on SAK and even on students' writing abilities. native and non-speaking students are aware of how difficult it is to write well many of students of English as a foreign language comes from abroad. Students these days don't put a strong emphasis on writing, which leads immensely to meeting their educational requirements. Development can be slowed as learners focus on the key roles including listening, chatting, or reading.

Students seeking innovative ideas have become a must in the face of this challenge that threatens them during their educational career. Efficient approaches are needed for learners. Using one of those strategies, teachers utilize instructional software such as the SmartBoard This research will examine the impact of introducing smart boards in the Southern Faculty of Education for improvement in the writing skills of female 9th graders in the Al-Zawahra.

\section{Significance of the study}

1) It may help students improve their writing skills by using a helpful tool such as smart boards.

2) It may provide a sample of information on how to employ Smartboards on the writing skills of teachers and students. 
3) It may be a beginning to further studies on different classes and different skills in the future

4) It may help teachers to improve and support their works with learners inside their classroom.

\section{Purpose of the study}

This study seeks to examine the potential impacts of having used Al-Mazarate English Smart Boards on developing the skills of ninth-grade female students.

\section{Question of the study}

This study tries to answer the following question:

1- $\quad$ Are there any statistically significant differences in the development of writing skills between the experimental group - (Smart Boards ) and the control group (conventional method) on ninth-grade female students in Southern Al-Mazar Directorate of Education?

\section{Operational Definition of Terms}

- Smartboard: is a new technology tool that connects computers to a whiteboard with USB, which allows using computers and whiteboard together interactively. This interaction helps transfer the information in the easiest way and for different purposes. It shows images and words in different shapes and ways and you can control what you see by touching the board and moving your fingers. Moreover, what is meant here in this study by Smartboard is the technological tool or method. A Smartboard looks like a regular board but it is more developed. The board is connected to a computer and provided with intelligent software that can simulate the work in digital information using audio-visual aids to help the learner improve their learning. This study focuses especially on the acquisition of writing skills that will be used on a group of students to measure their results and compare them before and after using this tool.

- Writing Skills: Writing is described as a framework; a collection of recognizable or tangible representations of language elements serves as a guide to each writing's codes and defines the rules under which the set of the writing system (Coulmas, 1999). The skills used in this research would focus on organizing ideas and writing as well as on clarifying them.

- Ninth Grade Students: students between 15-16 years old who have been studying English for 8 years in southern AL-Mazar Directorate of Education.

- Conventional Method: The method which is currently used in classrooms where the teacher sticks to what is in the teacher's book procedures and also dominates the class time, whereas students are inactive and only participate as listeners to the teacher who has the main role.

\section{Limitations of the Study}

This research is limited to ninth-grade female students and the English writing test developed by the researcher in Module 2 and 3. The study is also limited by time during the first semester for the year of 2017/2018, and spatial limits to Al-Mazar basic Schools and Mu'tah basic school for girls, in Southern Al-Mazar Directorate of Education.

\section{Theoretical Framework 2.1. What Is Writing?}


The major premise of this investigation is that writing is an important language ability. to discover how EFL students can control this ability in the English classroom is the key issue addressed in this report. So, an abbreviated introduction to writing can demonstrate the purpose, importance, and how it can improve the minds and brains of our students. it represents an utterance of such as can be more or less effortlessly. have investigated various types of universities in different countries (such as the USA, Germany, Japan, UK, France, etc.) to discover that the differences in government support (p.83). I write for two different reasons: I articulate myself and communicate with others. In general, we would have a clearer comprehension of the connection between representations and language itself. with this new notion of writing as visual contact, we can include the cave drawings in Lascaux (over a century old) and Altamash, Even the first marks found on bone in China date back 10,000 years, as well as the glyptic that was created 8,000 years ago by the Hittites, as well as the American carving that is still in use about 4,000 years old. It was from these attempts that current writing styles came into being, and it followed from there, regardless of their first experiences (Olson \& David, 2009). For a writing scheme to be complete, it must have a communicating purpose; it must use visual or electronic markers that apply to expression to form or programming in a manner that is compatible with conventions.

\section{1- The Beginning of Smartboard}

At the end of the 1980s, Smartboards were important to keep up with a new wave of technologies. Companies produced smart boards in 1991. At this point, the district did not afford to put the smart boards in all its classrooms. Just in 2009 were the bulk of the classrooms provided with SmartBoards. At long last, in 2011, more schools had SmartBoards installed (Pourciau, 2014).

David Martin and Nancy Knowl formed Smart Technologies in 1987 as a Canadian dealer for $3 \mathrm{M}$ projectors. Formal, digital whiteboards were developed and made for the workplace. Xerox PARC started designing them in the early 1990s. For informal community gatherings and discussions (Siegel, 2012).

Interactive boards have been added for the use of LCD screens on them. Intel established the study targets in 1992 and provided the funds to help them. coloured and lit markers had been mounted in the build, as well as the use of an eraser washer has transformed into a school seeking its most productive instrument, industry finds its most profitable field in the educational system (Greiffenhagen, 2002).

In the 2000s, as the world focused on electronics, technology, smartboard designs diversification did not end. The "first of its kind" company in the hardware and information business, "F technology" launched a truly mobile whiteboard application in 2001 Using wireless technologies, it allowed free mobility This opened up the possibility for educators and teachers to lecture from anywhere in the classroom without relying on technology.

\section{What is Smartboard / (Interactive Whiteboard) IWB?}

Many research and reviews come up with many different words for Smartboards. However, a concept with a broader scope is the "modern technical method applied to a data projector that can be applied directly to the whiteboard without going back to the machine."

A plethora of learning philosophies, such as Constructivism, Behavior Theory, Piaget's Developmental Theory, Neuroconstructivism, and Learning Styles, has been shown to students by means of immersive whiteboards. As students put in the time, they're sharpening their logical thought abilities. students are showing, communicating, displaying, playing, and modeling their understanding by using a SmartBoard. when using a Smartboard, a student's finger acts as the "the mouse" (Ladislaw, 2010). Overwhelmingly, if not all, previous study in 
this sector records the valuable impacts that teachers and/students earn from Smart Board technologies (Siegel, 2012).

\section{2- Integrate the Smart board in the Classroom}

Orlando and Davis (2012) detailed several explanations of how broad graphics, in particular, can aid in incorporating Smartboards into the classroom; in addition, students can use them to group knowledge and hold information as well as enhance their research skills. and so as well, work with students to help them with key concept structuring by utilizing photographs and text to create graphic organizers and outline resources Students employ the use of SmartBoards to acquire textual editing and revision skills Review is much better on the SmartBoard, because everyone will use different colors to help them find bits of expression and text, but use a different kind of highlighter to help the children concentrate on the responses. A student then interacts with the board to show responses that are correct. For several classes, a Gallery Tools project involves interesting items like story maps, images, flowcharts, and other opportunities for discovering knowledge on the internet. Projects produced by students or teachers can be shared in presentations. Do questionnaires that employ multiple choice and game questions.

\section{3- Smart board and Learning Style}

It is essential to examine how interactive whiteboards can aid in the educational process Educators actively seek out diverse and varied student interests in interventions and methods. Teachers can use the virtual whiteboard to assist with various teaching styles. It is indicated for children with vision, auditory, and hearing-impaired needs. It is possible to work with students who have differing learning patterns and requirements. Students who are visual learners profit from jotting down notes and controlling items as well as using the whiteboard with pictures and visual diagrams. It's an effective learning tool for children of all ages to see their own writing and things of their own design. Facial or fine-touch learners are usually challenging to get through with visual or auditory activities that are normal in classrooms They are able to increase retention of information and learning by contact and movement. Hearing and speechimpaired students use mainly visual learning strategies. Sign language is used along with visual content when presented on an interactive whiteboards They will deal with huge text on a whiteboard-sized computer screen, and do work like this in activities that cannot be done on a tiny screen. For physical problems such as ADD, as well as learning difficulties, the big interactive surface is useful because of its large scale and contact sensitivity (Paper, 2006).

\section{Literature Review}

An article by Momani et al. (2016) looks at the advantages of using a smart board while teaching English and examines possible difficulties in the process of using it at Tabuk high schools in Saudi Arabia. For certain issues, the researchers create a questionnaire for 30 native Saudi EFL teachers to resolve, It contains three parts. the findings of the study are discussed with the researchers so they can address the questions and assist in the creation of course syllabus design

Bataineh et al (2016) addressed the advantages of utilizing the smart board in ESL classroom scenarios They investigate the case of Majmah University, Majah College of PYP to analyze the advantages teachers' usage of the Smartboard. a survey was provided to the teachers. As a result, the researchers found certain results, which are as follows: utilizing intelligent boards in classrooms helps students collaborate, enhancing the connection between teachers and students, and in turn making them more relaxed with class sizes. 
In Jordan, Al-Majali evaluates the benefits of using Smart board for teaching social studies in public schools. The participants were divided into two classes, one being included in the experimental community and the other being a control group. The study party used a board when the control group did not. A pre-and-and-post-test was developed to assess the social sciences skill of the students Since conducting the trial, it was revealed that the experimental group enjoyed considerable gains in social studies over the control group.

to examine the feasibility of using SmartBoards to improve English 11 learners' vocabulary, reading performance, and attitudes toward English This researcher followed an experimental method of two experimental and control classes' the methods on the research participants $(85 \mathrm{men})$ were placed into use It was noticed that perceptions toward English favoured the experimental students after the introduction of the Smart Board. The findings showed substantial gaps in the control and experimental community assessments as a result of the impact of the Smartboard. There were major variations in the control and experimental community achievement between the students.

Reviews the electronic technology and one of the "Smartboards" in international or second language schools. The focus of this thesis is on the various ways of language learning and teaching in classrooms, their inefficiencies, and smartboard use in those contexts.

explore the impact of SmartBoard on students' impressions of classroom activities The analysis analyzed behavioural variations in 30-minute mathematics and science guidance, independent of whether it utilized a SmartBoard. A survey of student opinion offered approval for the usage of the Smartboard. Class involvement was comparable regardless of whether or not the students benefited by using the SmartBoard, however, fewer than half of the participants scored their attention and participation extremely when Smart Board was not available. further analysis is needed to decide whether incorporating smart board technologies into a useful instructional technique increases the participation of all pupils, demographics, and topics.

The study defines a class and an experience from Ladislaw, (2010). She concentrated on two students, one of whom she would describe as "using the conventional approach in the learning process" Since he used a SmartBoard as a training tool, he found a noticeable improvement in his academic performance and mindset. So as a result, she discovered that technology and particularly the Smart Boards are excellent resources to help the students' accomplishments and increase students' motivation.

Smart whiteboards are used in international language classes for different purposes. This describes how immersive whiteboards can be used to help with classwork. It presents how boards can help learning. The aim of this article is to expose the tool's vulnerabilities. The findings of this research could be positive in relation to language learning.

A comprehensive discussion of the benefits of Smart Boards, along with examples of their use in schools and workplaces, can be found in Greiffenhagen (2000). According to the current lack of study, additional input devices can help interact in the classroom and office environments. This is yet to be shown the whiteboards help in teaching and learning.

Gérard and Widener (1999) discussed intelligent boards and their impact on language learners whether they use this phase in their learning method. These four key theories were addressed throughout the discussion of this research. It refers to how both the teaching and learning processes can be made better with smart boards. However, it describes the issues that may be presented when using these boards. The researchers examine the question of whether smart boards are useful for language learning.

\section{4- Conclusion and Comments on Previous Literature}


The above studies demonstrate that Smart board strategies are relevant Additionally, in the studies it was found that using the SmartBoard learning technique was more successful than other approaches. in planning each day's lesson on the smartboard according to the expected technique Tara has developed: Al-Majali, et al (2016), Tarawneh (2017). Thus, the researcher was motivated to recognize the efficacy of the smart board method in learning English and writing skills. continued to include information on teaching patterns of writing tools, which refer to Yassin (2015) are seeing, describe what has happened to English writing over the decades as seen by Drbseh, and Hasan (2013). Lastly, this study is considered one of the first ones to do so in this area, as well as being part of an effort to better English language and teaching writing skills. Other experiments applied, for example, social studies, geometry but were not included in language studies.

\section{Design of The Study}

A quasi-experimental research design was employed for this research. This design depends on choosing two groups; the first is the experimental group, while the second is the control group.

\section{1- Population of The Study}

The population of the study consisted of 795 ninth grade female students who are studying at Al-Mazar directorate of education schools, during the first academic semester $2017 \backslash 2018$.

\section{2- Sample of The Study}

The sample of the study comprised of (67) ninth-grade female students at Al-Mazar directorate of education during the academic year 2017-2018.

The study sample was divided into two groups, the first is the experimental group with (31) students using Smartboard from Mu'tah basic school for girls, and the second is the control group with (36) students from Al-Mazar basic school.

The reason for selecting targeted schools is related to the fact that those schools are well equipped with computers with access to the internet and the existence of Smartboard, which is necessary for the application of the Smartboards as a learning method.

Equivalence of the two groups:

The T-test was used to indicate whether the two groups were equal and table (2) shows the results.

Table (1) T-test results for the equivalence of the two groups (interactive and traditional) on the post-test

\begin{tabular}{llllll}
\hline Test & Teaching Method & Number & Means & T-Value & Sig \\
\hline \multirow{2}{*}{ Before } & Smart Board & 31 & 31.096 & \multirow{2}{*}{0.629} & \multirow{2}{*}{0.532} \\
& Traditional Method & 36 & 31.805 & & \\
\hline
\end{tabular}

Table (2) shows that there is no difference between the experimental group taught by the smartboard method and the control group taught by the traditional method based on the value of $(T)=(0.629)$ at the level of $\alpha=0.532$ which is not statistically significant at $\alpha<=0.05$ This indicates that the two groups are equal.

\section{3- Instruments of the Study}

To achieve the purpose of the research, the researcher prepared the instrument which was (pre - post-test) to measure the students performance in writing skills before and after the treatment. A second instrument was prepared which is the lesson plane that applied on the experimental method and the conventional method.

\section{4- Validity of the Test}


To ensure the validity of the test, it was submitted to a jury of (10) specialists, as well as supervisors of English language and three teachers of English language. Each one of the specialists was handed a copy of the written test to provide their comments on it, to guarantee that the subject of writing and the grammar are convenient for ninth-grade students.

The initial copy of the test includes ten questions and each one includes a number of required sentences to be answered, it covers the writing required writing skills

After the jury judged the test, they suggested some minor changes on the items of the test questions, their comments were highly welcomed and taken into consideration. Some of the changes were eliminating two questions to become eight questions, spelling mistakes, structure mistakes, typing mistakes, adding sentences to cover the score of each question, omitting phrases, linguistics rearrangements between questions, and finally mark distribution according to the question level.

\section{5- Reliability of the Test}

To verify the reliability of the test, a Test-Retest technique was applied to the pilot study of (30) students from Khawlah bent Al-Azwar basic School, which were from the population of the study and excluded from the sample of the study. Two weeks later the same test for the same sample was implemented again. Reliability coefficient of scores of the test was calculated by using Person Correlation Coefficient and table (2) demonstrates the results.

\section{Table (2) Test-retest reliability coefficient}

\begin{tabular}{l|l}
\hline & Reliability coefficient value \\
\hline Test- retest & 0.886 \\
\hline
\end{tabular}

The results of table (3) demonstrate that the reliability value was (0.886), this value is considered high and appropriate for the current study.

\section{6- Instructional Material}

The material used in this study were unit (2 and 3) from English textbook (Action Pack $9^{\text {th }}$ grade, Virginia Paris, (2013), unit (2) entitled "The man who wear Kufiyyah" and unit (3) entitle "Will computers rule the world?" The main topics of those units are:1 - will vs. going to 2- future tense 3- conditional sentences type one 4- comparative and superlative 5- science fiction 6-computer revolutions.

Also to ensure the reliability of the material was submitted to a jury of professors and doctors. They judged the material and suggested some minor changes and additions such as using two units instead of one and applying them during the study to cover more writing skills. After that the units were computerized by using smartboard software that was used in the school, a number of presentations were prepared, the following steps were used of how the material presented to students.

\section{7- Procedures of the Study}

1. Reviewing the previous studies, which were relevant to the current study and related to writing, smart boards, technology, and learning material.

2. Having the official approvals from Mu'tah University and the permission from Al-Mazar Directorate of Education to conduct the study.

3. Selecting the schools where the two strategies are to be applied (Mu'tah basic School for girls and Al-Mazar basic school) .

4. The researcher selected randomly section (A) to be taught using smart boards from Mu'tah basic School for girls, section (B) to be taught using conventional method from Al-Mazar basic school.

5. The researcher designed the unit for the material that will be taught for students 
6. The researcher designed a lesson plan for the smart board, and a lesson plan for the conventional method according to the material that will be taught to students

7. The researcher checked with the teacher that the material main subjects structure is already had been given to students such as the following grammar (conditional sentences, comparative, future tense) for both sections, (A) (smartboard method) and (B) (conventional method) both of them were taught firstly by a conventional method.

8. The researcher gave the exam (pre-test) for both of groups (A, smartboard method) and (B, conventional method) and asked students to answer the questions about comparative, will vs. going to, and simple future grammar with science fiction vocabulary, which are in the textbook.

9. The researcher with another teacher corrected students` papers by using a writing rubric.

10. The researcher started the process of teaching group (A, smartboard method) as the following:

a- The researcher presented several power points about general information about the Smartboards revolution, science fiction, and computer revolution (previous classes) by using the smartboard before starting with explaining the unit's main subject it took one class (50 minutes) to present the power points.

b- The researcher explained the technical usage process for the smartboard according to the used software and hardware. Also, she explained the internal and external icons related to the smart board in front of them. It has been covered through the previous class while presenting the power points.

c- The researcher started with explanations for the unit subjects and the grammar mentioned in the units by using the smart board and its interactive software each subject for one class a total of six classes (50 minutes each class) to cover the whole subjects.

d- Three weeks after, the researcher introduced the post-test and asked students to answer the questions of the same test that they had for the week before.

11. Students in the control group section (B) were taught in a room with a table, a board, and desks: using the main whiteboard and talk.

a- The researcher starts with students for the unit subjects and the grammar mentioned above (comparative, will vs. going to, and conditional sentences) Each subject for one class was spread over a total of six classes to cover the whole units.

b- Three weeks later, the researcher gave another exam (post exam) after finishing the targeted covered material and asked students to answer the questions of the same exam that they had.

c- The researcher with another teacher corrected students` papers by using a writing rubric.

12. Collecting data from both groups and analyzing it using the statistical Package for Social Sciences (SPSS).

13. Results were obtained and discussed.

14. Recommendations were proposed to the concerned parties.

\section{Statistical Analysis}

To answer the question of the study, T-Test for the independent samples and T-test for the paired sample used.

\section{Results of the research}

The results of the research question: Are there any statistically significant differences at level $(\mathrm{a}<=0.05)$ in the development of writing skills between the experimental group (Smart Boards method) and the control group (conventional method)? 
To answer this question, T-test for independent and paired sample were used, the tables (4) show the results:

Table (3)Results of paired sample T-test to show the differences between the means of Traditional Method and smartboard group on the pre-post test.

\begin{tabular}{llllll}
\hline Group & Test & Number & Means & T-Value & Siq \\
\hline Traditional & Pre & 36 & 31.08 & -1.816 & 0.078 \\
Method & Post & 36 & 32.63 & & \\
Smart Board & Pre & 31 & 31.09 & $7.067-$ & 0.000 \\
& Post & 31 & 35.22 & & \\
\hline
\end{tabular}

* Statistically significant at level $(\mathrm{a}<=0.05)$

The result in table (3) shows there are no differences in the means of traditional method group on two tests (before - after) based on (T-test) value and it's significant and there is a difference in the means of SmartBoard group in the two tests (before - after) based on (T-test) value the difference is in favor of post-test with a Mean of (35.22).

Table (4) Test results for T-test to show the differences between the two groups studied in the smart board and traditional method.

\begin{tabular}{lllllll}
\hline Test & Teaching Method & Number & Means & T-Value & Siq & Eta Square \\
\hline \multirow{2}{*}{ Post } & Smart Board & 31 & 35.22 & \multirow{2}{*}{$* 3.064$} & \multirow{2}{*}{0.003} & \multirow{2}{*}{0.126} \\
& Traditional Method & 36 & 32.63 & & & \\
\hline
\end{tabular}

* Statistically significant at level $(\mathrm{a}<=0.05)$

The result in table (3) shows that there is a difference in the means of two group (smart board, Traditional Method) on after test, based on (T-test) value and its significant shown in table (5), the difference in favor of Smart Board group with a Mean of (35.22).

\section{Results related to the question of the study}

statistical (+) 0.0004. This table shows that the values of the independent variable between the two classes are significantly different at $(\mathrm{T}=3.64)$ standard deviation of (confidence $<0.05$ ). The results are more favorable for the community trained using the smartboard approach (31.66) than for the test group (31.5). This suggests that Al-Mazadriz has a very large influence on English writing skills in 9th grade.

\section{Discussion}

Studies indicate that there were substantial variations between the two sets of subjects who had been trained using the conventional teaching approach and those that had not. The findings favored the study community. the impact size was $12.6 \%$

This can be due to the usage of the Smartboard stimulating students' desire to develop their writing skills. This is definitely focused on the students' comments showing they will do work on another lesson or unit on paper first and their great intent to practice the previous year's lessons/work on board using interactive devices, then they'll wait before class begins before having the next year's. A number of excited moments in class demonstrate student motivation as well. All in this song may be connected with teaching, for that matter, and it could also be associated with the application of technology today's methods of training. In addition, the use of the Interactive Smart Board method helped to simplify the concepts and terminology of the English language and enabled them to write to an order that enabled the students to improve their writing experience. The researcher explained this result based on the ability of this method to develop the skill of writing through the feedback of using smart board that designed to teach students the whole class. 
Furthermore, the feedback provided by the smart board among students may be a contribution to improve the writing skills of the students, thus helping to acquire writing skills. The researcher also attributes this result to the ability of this method to help the student with the retention of the educational content, which helped them to be easy to retrieve in the exam.

Additionally, the researcher also attributes the result that the use of smart board in teaching contributes to the improvement of the level of achievement of students in general and in particular in the acquisition of writing skills. It also encourages and stimulates the student's motivation and personal orientation towards the educational material because the student is currently more connected to technology and uses it frequently so it became a reliable and important source for information.

The researcher attributes this result to the effectiveness of teaching using the smart board in helping the student to know the shape of the character in English and ease to recall and call information when needed, which helps develop the skill of writing.

This finding may be explained by the fact that the use of information technology in the Smart Panel has fueled the motivation of students to learn, having received their satisfaction help students to take roles, motivate them and helped them demonstrate their skill in using modern technology, which is reflected on the development and improvement of their writing skills.

Moreover, this result may explain that the design of the Smart board to teach all students, in contrast to the computer designed to be used by one individual, has improved the skills of communication and developed social interaction between students and teachers. It has also improved the relations of students and this technology and students and teacher so that the student watched by everyone has helped to improve the collective's ability to write in English.

Admittedly, the Smart Panel as technology means the student feels dynamic, and being dynamic has a positive side, which is reflected in the improvement of writing skill. It is one of the means of collaborative learning, which has improved the skill of writing for students and may explain this result on the basis that the smartboard helps and encourages the student to use all senses, which helped to improve the skill of writing them.

The results of the study correlate with the results of these studies; Gérard and Widener (1999), Al Majali, et al., (2016), Greiffenhagen, (2002), Paper, (2006), (Bataineh et, al, 2016), and Al Farra, 2014

\section{Recommendations}

Based on the findings of the study, the following recommendations were proposed:

1- Encouraging English language teachers in the schools of the Ministry of Education to use the Smartboard Method to improve the writing skills of English language students.

2- The researcher recommends conducting more research and studies on the effectiveness of using Smartboards in acquiring other English language skills such as reading and listening.

3- Conducting more research on the effectiveness of this method in improving writing in English at other stages of study, such as the basic stage.

\section{REFERENCES}

Al Farra, R. (2014). The effectiveness of using smart boards in developing tenth graders' vocabulary achievement, retention, and attitudes towards English in Gaza. The Islamic University-Gaza, Gaza.

Al-Besher, K. (2012). Developing the writing skills of ESL students through the collaborative learning strategy (Doctoral dissertation), Newcastle University. 
Al-Majali, H. K., Al Abdallah, S. E., \& Shamayleh, N. (2016). The effectiveness of using smartboard for teaching social studies at public schools in Jordan. Global Science Research Journal, 4(1), 227-233. http://www.globalscienceresearchjournals.org/

Bataineh B , Mohammed A , \&Yaghi E (2016) The importance of using Smart Boards in teaching small EF classes. A case study of college of preparatory year programs(PYP), Majmmah University, KSA, International Journal on Studies in English Language and Literature (IJSELL) 4(5), 9-17, http://dx.doi.org/10.20431/2347-3134.0405002

Costley, K. C. (2014). The positive effects of technology on teaching and student learning. Online submission.

Coulmas F, (1999) The Blackwell Encyclopedia of Writing Systems (Oxford, Blackwell,1999), P.560.

Drbseh, M. M. H., \& Hasan, M. (2013). The spread of English language in Jordan. International Journal of Scientific and Research Publications, 3(9), 1-5.

Gérard, F., \& Widener, J. (1999). A SMARTer way to teach foreign language: The SMART board interactive whiteboard as a language learning tool. Retrieved August, 23, 2010.

Greiffenhagen, C. (2002). Out of the office into the school: electronic whiteboards for education. produced by Oxford University Computing Laboratory.

Momani, M., Alshaikhi, T. S., \& Al-Inizi, T. H. (2016). The obstacles of using smart board in teaching English at Tabuk secondary schools. Asian Journal of Educational Research, 4(3), 24-26.

Muslim, I. M. (2014). Helping EFL students improve their writing. International Journal of Humanities and Social Science, 4(2), 105-112.

Nasir, L., Naqvi, S. M., \& Bhamani, S. (2013). Enhancing students' creative writing skills: An action research project. Acta Didactica Napocensia, 6(2), 27-32.

Olson F, \& David R. (2009). The history of writing/ online published paper/ http://journals.sagepub.com/home/wcx

Orlando A,\& Davis E, (2012) "21 ways to integrate the SMART board in the elementary classroom" /4th grade teacher Sean Mason, Special Education Teacher

Paper A, (2006). Interactive whiteboards and learning improving student learning outcomes and streamlining lesson planning /SMART Technologies Inc.

Pourciau, E. L. (2014). Teaching and learning with smart board technology in middle school classrooms. Chief Academic Officer Eric Riedel, (PhD thesis)/Walden University

Siegel, E. (2012). Interactive whiteboards in education: Are They Worth It?online published paper

Tarawneh R , (2017). The effect of using VAK model and web quest strategy on developing writing skills in English language of tenth graders` in schools of the southern AL-Mazar Directorate of Education (Master thesis ) TEFL/Mu'tah University.

Yassin. B, (2015) Challenges of teaching English language to English language learners at Private Universities in Jordan. Arab World English Journal (AWEJ)6. (2). 265 - 274. https://dx.doi.org/10.2139/ssrn.2834395

\section{AUTHOR'S BIO}

Ms. RAFAH AWAD ABD AL-SALAM TARAWNEH is a PhD Scholar at Mu'tah University, Jordan. She has been teaching English for the past 10 years; she is a qualified trainer in the fields of entrepreneurship and labor market. Her research interests include EFL teaching and learning strategies, and second language acquisition. 